\title{
Biological Markers of Recurrence and Survival of High-Grade Gliomas: The Role of Hepatocyte Growth Factor
}

\author{
Roberto García-Navarrete1,2,3, Esperanza García Mendoza1, \\ Alfonso Marhx-Bracho ${ }^{2}$ and Julio Sotelo ${ }^{1}$ \\ ${ }^{1}$ Neuroimmunology Unit, Instituto Nacional de Neurología y Neurocirugía \\ ${ }^{2}$ Neurosurgery Department, Instituto Nacional de Pediatría \\ ${ }^{3}$ Hospital General Naval de Alta Especialidad, Armada de México \\ México
}

\section{Introduction}

Malignant gliomas - the most frequent glial tumor of Central Nervous System (CNS) anaplasic astrocytoma and glioblastoma multiforme, are regarded by the World Health Organization as the form of cancer with the worst prognosis in humans. Its biological behavior and severity are associated with increased concentrations of various growth factors, like fibroblastic growth factor (FGF), vascular endothelial growth factor (VEGF), platelet-derived growth factor (PDGF) and hepatocyte growth factor (HGF).

Hepatocyte growth factor (HGF) is a pleomorphic protein with several properties. It was described in 1996 as a protein related to cell proliferation and motility in the rat liver. It has also been associated with morphogenesis of the central nervous system in mammals. HGF has been associated with proliferation of several cell lines, for example carcinoma of colon, stomach, gallbladder, pancreas, and breast. In human gliomas high intratumoral concentrations of HGF and its receptor c-met are associated with poor prognosis; it has also been associated with long-time recurrence of meningioma. In vitro, transfer of the HGF gene increases tumorigenicity, growth, and angiogenesis; interestingly, inhibition of this gene reduces growth rate and malignancy in experimentally induced-glioma in rats.

Human studies have shown that HGF contents in blood (Wen et al. 2011) are closely related with malignancy of glioma; low-grade glioma shows a lower intratumoral concentration of HGF than high-grade glioma.

Recently, we have found HGF directly related in human gliomas to increased angiogenesis, cellular proliferation, resistance to apoptosis induced by gamma radiation, and invasion of healthy tissue along white matter tracts. All of these features are characteristic of malignancy.

In the clinical setting, high HGF levels in cerebrospinal fluid predict mortality and a short disease-free time in patients with malignant glioma, and helps to explain the great variance observed on survival of patients with malignant glioma, suggesting that HGF inhibition strategies could be a useful means of improving survival and disease-free time among glioma patients. 
Thus, experimental and clinical findings suggest that HGF is a good target for therapeutic strategies with pharmacogenomic methods and could be useful as a biological marker for monitoring malignant gliomas activity.

\section{Malignant glioma}

Intracranial neoplasms include a great diversity of tumors with different histopathologic origins, prognoses and treatments: Malignant gliomas such as anaplasic astrocytoma (AA) and glioblastoma multiforme (GM) are the most frequent glial tumors: their incidence is $4 / 100,000$, and they account for $2 \%$ of all malignant tumors in adults. Malignant gliomas are associated with poor prognosis; the mean survival time of patients with GM is one year, this gloomy picture has not changed significantly for the last three decades. Similarly, the survival for patients with AA is minor than three years. Therefore, it is of paramount importance to understand the pathophysiology of malignant glial tumors and identify prognostic factors. Both GM and AA have high proliferation and intense vascularity, features closely related with malignant cell growth.

Malignant conditions are related to ability of malignant cells to produce growth factors such as vascular endothelial growth factor (VEGF), platelet derived growth factor (PDGF), and fibroblastic growth factor (FGF) (Arrieta et al., 2002).

Due to their invasive nature, glioblastomas cannot be resected completely by surgery and, despite the progress of neurosurgical techniques and radio/chemotherapy, less than a half of patients survive more than a year, aged subjects have the most significant adverse prognostic factor.

Glioblastoma is the most frequent malignant tumor of the brain, it account for approximately $12-15 \%$ of all intracranial neoplasms and $60-75 \%$ of astrocytic tumors (Lantos et al., 2002; Lois et al., 2007). In most European and North American countries, the yearly incidence is in the range of 3-4 new cases per 100000 population (Lois et al., 2007).

\subsection{Prognostic factors}

Despite progress in surgery, radiotherapy and chemotherapy of brain tumors, the overall survival of patients with glioblastoma remains dismal. Population-based studies from Switzerland and Canada have shown that less than $20 \%$ of patients survive more than one year after diagnosis and less than 3\% lived longer than 3 years (Lantos et al., 2002; Ohgaki et al., 2007). Clinical trials show a slightly better prognosis, with median survival rates of approximately 12 month; however, they have strong bias toward the recruitment of younger patients and those with higher preoperative Karnofsky performance scores, both are strong predictors of a more favorable clinical outcome.

Virtually all therapy trials have shown that younger glioblastoma patients $(<50$ years at diagnosis) have a significantly better prognosis (Lois et al., 2007). In a large populationbased study, age was the most significant prognostic factor; persisting through all age groups in a linear manner (Ohgaki et al., 2007). Patients with secondary glioblastoma survived significantly longer than those with primary glioblastoma, but this is likely due to their age rather than a reflection of a different biological behavior.

The prognostic value of TP53 mutations in glioblastomas is controversial, it either shows no association or the presence of TP53 mutations was a favorable prognostic factor. In a large population-based study, the presence of TP53 mutations was predictive of longer survival but this was not significant when adjusted for younger age. 
There is no consistent correlation of epidermal growth factor receptor (EGFR) amplification with survival largely irrespective of the age at first clinical manifestation. LOH 10 (Lois et al., 2007) is the most frequent genetic alteration in glioblastoma and is associated with reduced survival. The presence of PTEN mutations is not associated with prognosis of glioblastoma patients (Lois et al., 2007).

Since the initial histological description of astrocytic neoplasms, several efforts have been made to identify biomarkers that could predict the biological behavior of the tumor. However, to date only few peptides been identified substances that show a weak association with prognosis.

\section{Biological markers of glioblastoma activity}

The following paragraphs describe some substances that have been reported as candidates for surveillances of tumor activity by measuring their contents in serum.

A molecular event determining the development of malignancy is the activation of bcatenin, a protein necessary for the alignment and maintenance of epithelial cells by regulating cell growth and cell adhesion. The coexpression of $\alpha$-catenin reduces the cellular growth and migration induced by EGF on human glioma cells (Ji et al., 2010).

A secreted protein of unknown function, YKL-40 (chitinase-3-like-1), is overexpressed in glioblastoma [4], its presence is associated with LOH 10q (Lois et al., 2007), poorer radiation response, shorter time to tumor progression and reduced overall survival (Ohgaki et al., 2004). It is typically coexpressed with matrix metalloproteinase-9 (MMP-9), and its detection in serum has been used to monitor patients with recurrent tumor growth (Pelloski et al., 2005). One report showed that increased expression of GD3 synthase mRNA, in combination with decreased GalNAcT, correlate with an increased survival of patients with glioblastoma (Hormingo et al. 2006).

\subsection{Growth factors}

The expression of growth factors and their receptors are associated with glioma malignancy. Thus, their potential therapeutic importance has been demonstrated using specific inhibitors of growth factors in experimental and clinical studies. However, recent results have shown that glioma cells are resistant to this treatment and illustrate the therapeutic difficulties in malignant gliomas.

\subsection{Vascular endothelial growth factor}

Vascular endothelial growth factor (VEGF) is a signal protein that stimulates vasculogenesis and angiogenesis; VEGF's normal function is to induce growth of vessels during early developmental stages, after injury, at muscle following exercise, and to generate new vessels to bypass blocked arteries. When VEGF is overexpressed, it can contribute to malignant glioma progression. Cancers that express VEGF grow and metastasize, VEGF belongs to platelet-derived growth factor family. They are involved in both, vasculogenesis, the novo, and angiogenesis (Mentlein et al., 2004; Reux et al., 2006).

Within the major growth factors related to angiogenesis, VEGF is one of the most important. In several tumors, VEGF plays a pivotal role for vascularization necessary to supply the malignant tissue with oxygen and nutrients. Human glioma cells are characterized by high production of VEGF, however, functional and autocrine growth stimulatory effects on glioma cells are minor (Reux et al., 2006). 
In recurrent GBM trials with temozolomide shown a poor therapeutic response where as VEGF inhibitors as bevacizumab, improve the response rate by $25 \%$ to $74 \%$, and the periodfree of symptoms increases by $32 \%$ to $64 \%$, which is superior to the rate reported for temozolomide alone (Pope et al., 2006; Guiu et al., 2008; Narayana et al., 2009; Nghiemphu et al., 2009; Poulsen et al., 2009; Zuniga et al., 2009). The main effect of VEGF inhibitors is centered on rapid reduction in peritumoral edema, improving corticosteroid use. These studies also indicated that bevacizumab treatment is well tolerated and the risk of intratumoral hemorrhage is low. Toxicity related to bevacizumab therapy in patients with malignant glioma includes hypertension, proteinuria, fatigue, thromboembolic events, and wound-healing delay.

\subsubsection{Epidermal growth factor}

Epidermal growth factor (EGF), is a prototype member of the EGF-family of peptides which have highly similar structural and functional characteristics. Other peptides include: Transforming Growth Factor- $\alpha$ (TGF- $\alpha$ ), amphiregulin, epiregulin, and neuregulin 1-4, all of them related to tyrosine kinase activity which initiates a signal transduction cascade that result in several changes: rise in intracellular calcium contents, increased glycolysis, protein synthesis, DNA synthesis and cell proliferation (Fallon et al., 1984).

EGF is overexpressed in various cancers; malignant glioma, breast, pancreas and liver carcinoma, indicating its main role in malignant cell transformation, tumor occurrence and growth by promoting cell division (Xian et al., 2001). Recent reports show that $+61 G$ polymorphism of EGF gene increase the risk for glioma development in European subjects but are a protective factor in Chinese subjects (Tan et al., 2010).

The Epidermal growth factor receptor (EGFR) gene is amplified and overexpressed in approximately $40 \%$ of patients with primary GBMs. Increased EGFR signaling drives tumor cell proliferation, invasiveness, motility, angiogenesis, and inhibition of apoptosis. Attempts to identify biomarkers to help predict response to EGFR inhibitors have yielded conflicting results. Currently, there is no convincing evidence of a correlation between EGFR expression in tumoral tissue and prognosis (Van Meir et al., 2010).

\subsubsection{Hepatocyte growth factor}

Hepatocyte growth factor (HGF), also called scatter factor, is a multifunction protein with strong mitogenic effect on hepatocytes. It was initially isolated as a peptide related to hepatic regeneration. It is considered a reliable indicator of hepatic function alter hepatectomy. This protein is constituted by a heavy chain $(60 \mathrm{kD})$ with four domains and a Light chain (32 kD); it binds through its tirosine-kinase receptor, a product of the protooncogene c-Met. Hepatocyte growth factor, secreted by mesenchymal cells, acts as a paracrine effector on different epithelial cells inducing mitogenesis and stimulating cellular motility. It is also a powerful angiogenic factor for endothelial cells in vitro and in vivo. In the liver and kidney, it may have a role as antiapoptotic (Xiao et al., 2001). It is also necessary for embriogenesis as regulator of cell migration and growth. Hepatocyte growth factor is also produced by other cells, such as osteoclasts, participating in the regulation of bone remodeling; its production by monocytes has a role in the regulation of hematopoyesis by stimulation of growth and differentiation of erythroid precursors (Arrieta et al., 2002).

Knockout mice for the HGF gene develop severe abnormalities in the liver, placenta, and nervous system causing fetal death. A direct genetic relation between HGF and cancer has 
also been recently proposed due to mutations in the catalytic domain of c-Met from patients with renal carcinoma. Overexpression of HGF is present in various cells lines of leukemia and lymphoma and in solid tumors of the breast, prostate, colon, liver, kidney, uterine cervix, endometrium, and bladder (Arrieta et al., 2002). Hepatocyte growth factor also promotes adhesion and migration of cancer cells, due to the high affinity of integrins to their ligands, a phenomenon related to the metastatic tendency of carcinomas (Trussolino et al., 2000; Arrieta et al., 2002).

Normal human astrocytes express HGF and its receptor c-Met (Yamada et al, 1994). Met is a proto-oncogene that when mutated can transform a variety of cell types; the Met receptor is a heterodimer consisting of an extracellular alpha chain and a trans-membrane beta chain, which is a tyrosine kinase, it is widely expressed by epithelial and endothelial cells as well as melanocytes, chondrocytes, skeletal muscle, hematopoietic, lymphoid, and neural cells. The activation of Met by HGF binding is linked to cell growth and survival, including the avoidance of anoikis which is apoptosis induced by insufficient association with cell-matrix, through activation of both the PI3-kinase/PDK/Akt and the Ras/Raf/MEK/ERK pathways and to cell mobility and cytoskeletal organization via activation of the Rho-GTPases, Rho, Rac and CDC (Arrieta et al., 2002).

Activation of Met tyrosine kinase also activates phospholipase $C$, resulting in the elevation of intracellular calcium and activation of conventional and novel protein kinase $C$ pathways. HGF and Met have been associated with progression, invasiveness and metastasis in a number of neoplasms. Met is expressed in a wide variety of carcinomas, musculoskeletal tumors, soft tissue sarcomas, glioblastoma, astrosarcoma, and several hematopoietic malignancies. HGF Met signaling is a major potential target for the development of cancer therapeutics.

\subsubsection{Hepatocyte growth factor and malignant gliomas}

As HGF, its receptor c-met has been implicated in the genesis, malignant progression, and chemo/radioresistance of multiple human malignancies, including gliomas (Peruzzi et al, 2006; Carapancea et al, 2009; Hadjipanayis et al, 2009a, 2009b). Experimental studies using transient expression of anti-SF/HGF and anti-c-met U1snRNA/ribozymes suppress SF/HGF and c-met expression, c-met receptor activation, tumor cell migration, and anchorage-independent colony formation in vitro. The delivery of U1snRNA/ribozymes to established subcutaneous glioma xenografts via liposome-DNA complexes significantly inhibited tumor growth as well as tumor SF/HGF and c-met expression levels. Histological analysis of tumors treated showed a significant decrease in blood vessel density, increase in activation of the pro-apoptotic enzyme caspase-3, and increase in tumor cell apoptosis. Treatment of animals bearing intracranial glioma xenografts with anti-SF/HGF and anti-cmet U1snRNA/ribozymes substantially inhibited tumor growth and promoted animal survival (Abounander et al, 1999, 2002; Kim et al, 2006).

The use of monoclonal antibodies against the NK23 and NK422 domains of the HGF reduce tumor growth and mitotic rate (Bhargava et al., 1992; Boros et al., 1995; Kimura et al., 1995; Miwa et al., 1997; Neaud et al., 1997; Takeuchi et al 1997; Stella et al., 1999; Grierson et al., 2000; Cao et al, 2001; Brockmann et al, 2003; Burgess et al, 2006); Also, viral transgenes against HGF-RNA reduce invasion of white matter tracts, improving response to radiotherapy (Lal et al, 2005; Chu et al, 2006).

The therapeutic efficacy of SGX523 has recently been proven in human brain tumors. It seems that SGX523 inhibits c-Met, AKT and MAPK phosphorylation, cell proliferation, cell 
cycle progression, migration and invasion in different human glioblastoma cell lines, glioblastoma primary cells, glioblastoma stem cells and medulloblastoma cell lines. Importantly, oral administration of SGX523 to mice bearing intracranial human glioma xenografts led to inhibition of tumor growth in vivo. This experimental data suggests that cMet kinase inhibition is a feasible and promising approach for brain tumor therapy (Guessous et al., 2010).

\section{HGF and gliomas on clinical setting}

Hepatocyte growth factor and its receptor (c-Met) have been detected in normal astrocytes as well as in human gliomas, and other malignant tumors (Koochekpour et al., 1995; Nabeshima et al., 1997; Hirose et al., 1998). In human cultured glioma cells, HGF and c-Met are simultaneously expressed, with an autocrinous effect inducing cell proliferation and migration.

Recent findings suggest that HGF contributes to glioma progression, inducing angiogenesis and expression of additional angiogenic autocrine factors such as VEGF (Laterra et al., 1997; Lamszus et al., 1999; Moriyama et al., 1999; Schmidt et al., 1999). The overexpression of HGF and its receptor c-Met increases cell motility and proliferation of human glioma cells in vitro (Koochekpour et al., 1995).

Intratumoral concentration of HGF in malignant gliomas is greatly increased in comparison with other intracranial tumors and nontumoral brain tissue (Arrieta et al., 2002); it is also related to cell proliferation and peritumoral edema, showing its participation in the pathogenesis of these tumors.

A common cause of failure of treatment of malignant gliomas is resistance to radiotherapy and chemotherapy; the mechanism by which the cell survives to therapeutic attempts involves the production of growth factors that regulate DNA repair and apoptosis. In vitro and in vivo, HGF inhibits drug-induced cytotoxicity and apoptosis in experimental neoplasms treated by radiation, cisplatin, and camptothencin (Bowers et al., 2000); this effect might decrease the therapeutic response of patients with high intratumoral contents of HGF. There is intense infiltration by microglia in gliomas, which may enhance malignancy by secretion of epidermal growth factor and by inhibition of cytotoxic lymphocytes (Wood et al., 1983); in vitro HGF stimulates the microglial infiltration of gliomas, favoring their growth (Badie et al., 1999).

The direct correlation of cell proliferation with the presence of HGF supports its participation in the promotion of tumoral growth of glioma, as has been shown for other tumors such as breast carcinoma (Lamszus et al., 1997).

The mechanism by which HGF stimulates cell proliferation seems to be related to the tirosine kinase activity of its receptor, which involves Ras and mitosis activation proteins (Arrieta et al., 2002). Such effects can be antagonized by tirosine kinase inhibitors. However, not all HGF effects require phosphorylation of its receptor; for instance, its antiapoptotic effect is independent, suggesting that it could also participate in the genesis of the tumor. The insertion of the HGF gene in human glioma cells increases proliferation of independent colonies in vitro and tumorigenesis in vivo (Laterra et al., 1997).

There are some histological features of malignant glioma associated with prognosis, such as the extent of necrosis or vascular density (Barker et al., 1996). Hepatocyte growth factor is a strong inductor of angiogenesis; its effects are synergistic with other growth factors such as VEGF and bFGF. Intratumoral concentration of HGF shows a direct relation with 
peritumoral edema, independent of vascular density. Previous studies have shown that HGF increases the permeability of the hematoencephalic barrier, independently of VEGF expression, possibly by the induction of endothelial fenestrations and by the tumoral expression of proteases such as urokinase and extracellular matrix metalloproteinases (Book et al., 1999).

A paracrine loop for HGF effects related with migration of tumor cells along white matter has been described. The increase of HGF in CSF observed may therefore reflect either the transport of HGF from brain parenchyma to the ventricular system or the diffusion of HGF along the subarachnoid space (Garcia-Navarrete et al., 2010).

HGF concentration is closely related with malignancy of glioma; low-grade glioma shows a lower intratumoral concentration of HGF than high-grade glioma. CSF concentrations of HGF greater than $850 \mathrm{pg} / \mathrm{ml}$ prior to surgery was predictive of a shorter disease-free time among malignant glioma patients than was observed for patients with a lower concentration (6 \pm 0.6 months $(95 \%[\mathrm{CI}], 5-7)$ vs. $9 \pm 0.5$ months (95\% [CI], 8-10), respectively, $\mathrm{p}<0.001)$, besides total-gross resection surgery (Garcia-Navarrete et al., 2010). CSF concentration of HGF shows a negative correlation with survival of patients with malignant glioma and explains with high certainty the variance for survival. This suggests that HGF could be a good target candidate for molecular therapy such as RNA interference, by silencing the specific gene for HGF.

Although HGF seems a good target for therapeutic attempts, a phase II study reported the use of a monoclonal antibody against HGF (AMD 102). This study was conducted in patients with histopathologically confirmed diagnosis of GBM, gliosarcoma and history of more than 3 relapses; increases up to 10 times the basal levels of HGF in patients during treatment with AMD did not induce changes in survival time or clinical status as compared with controls (Wen et al., 2011)

\section{Conclusions}

To date, there is no biological marker that can accurately discern the activity of malignant gliomas. The scientific evidence obtained from experimental studies suggests that Hepatocyte Growth Factor plays a crucial role in the pathophysiology of high-grade gliomas. Findings from clinical studies suggest that HGF may be considered a distinguishing marker of biological activity of malignant gliomas, as it has been consistently demonstrated that the intratumoral, cerebrospinal fluid and serum concentrations are directly associated with prognosis and survival. The results of clinical trials aimed to evaluate the role of inhibitors of HGF or its receptor c-Met have shown disappointing therapeutic results. However, scientific advances in molecular biology could improve the response to treatment with specific inhibitors of HGF metabolism through ingenious genomic manipulations in patients with malignant gliomas.

\section{References}

Abounader R, Lal B, Luddy C, Koe G, Davidson B, Rosen EM, Laterra J (2002) In vivo targeting of SF/HGF and c-met expression via U1snRNA/ribozymes inhibits glioma growth and angiogenesis and promotes apoptosis. FASEB J. Vol. 16, No. 1, pp. 108-10. PMID - 11729097 
Abounader R, Ranganathan S, Lal B, Fielding K, Book A, Dietz H, Burger P, Laterra J (1999). Reversion of human glioblastoma malignancy by U1 small nuclear RNA/ribozyme targeting of scatter factor/hepatocyte growth factor and c-met expression. J Natl Cancer Inst. Vol. 91, No. 18, pp. 1548-56. PMID - 10491431

Arrieta O, Garcia E, Guevara P, Garcia-Navarrete R, Ondarza R, Rembao D, Sotelo J. (2002). Hepatocyte growth factor is associated with poor prognosis of malignant gliomas and is a predictor for recurrence of meningioma. Cancer. Vol. 15, No. 94, 3210-8. PMID- 12115353

Badie B, Schartner J, Klaver J, Vorphal J. (1999). In vitro modulation of microglia by glioma cells is mediated by hepatocyte growth factor/scatter factor. Neurosurgery. Vol. 44, No. 5, pp. 1077-82. PMID - 10232541

Barker FG 2nd, Davis RL, Chang SM, Prados MD. (1996). Necrosis as a prognostic factor in glioblastoma multiforme. Cancer. Vol. 77, No. 6, pp. 1161-66. PMID - 8635139

Bhargava M, Joseph A, Knesel J, Halaban R, Li Y, Pang S, Goldberg I, Setter E, Donovan MA, Zarnegar R, Michalopoulos GA, Nakamura T, Faletto D, Rosen EM.. (1992). Scatter factor and hepatocyte growth factor: activities, properties and mechanism. Cell Growth Differ. Vol. 3, No. 1, pp.11-20. PMID - 1534687

Boros P, Miller CM. Hepatocyte growth factor: a multifunctional cytokine. Lancet. Vol. 345, No. 8945, pp. 293-95. PMID - 7837864

Bowers DC, Fan S, Walter KA, Abounader R, Williams JA, Rosen EM, Laterra J. (2000). Scatter factor/hepatocyte growth factor protects against cytotoxic death in human glioblastoma via phosphatidylinositol 3-kinase- and AKT-dependent pathways. Cancer Res. Vol. 60, No. 15, pp. 4277-83. PMID - 10945642

Brockmann MA, Papadimitriou A, Brandt M, Fillbrandt R, Westphal M, Lamszus K (2003) Inhibition of intracerebral glioblastoma growth by local treatment with the scatter factor/hepatocyte growth factor-antagonist NK4. Clin Cancer Res. Vol. 9, No.12, pp. 4578-85. PMID - 14555533

Burgess T, Coxon A, Meyer S, Sun J, Rex K, Tsuruda T, Chen Q, Ho SY, Li L, Kaufman S, McDorman K, Cattley RC, Sun J, Elliott G, Zhang K, Feng X, Jia XC, Green L, Radinsky R, Kendall R (2006). Fully human monoclonal antibodies to hepatocyte growth factor with therapeutic potential against hepatocyte growth factor/c-Metdependent human tumors. Cancer Res. Vol. 66, No. 3, pp. 1721-29. PMID - 16452232

Bussolino F, Di Renzo MF, Ziche M, et al. Hepatocyte growth factor is a potent angiogenic factor which stimulated endothelial cell motility and growth. J Cell Biol. Vol. 119, No. 2, pp. 629-41. PMID - 1383237

Cao B, Su Y, Oskarsson M, Zhao P, Kort EJ, Fisher RJ, Wang LM, Vande Woude GF (2001). Neutralizing monoclonal antibodies to hepatocyte growth factor/scatter factor (HGF/SF) display antitumor activity in animal models. Proc Natl Acad Sci USA. Vol. 98, No. 13, pp. 7443-48. PMID - 11416216

Carapancea M, Alexandru O, Fetea AS, Dragutescu L, Castro J, Georgescu A, Popa-Wagner A, Bäcklund ML, Lewensohn R, Dricu A. (2009). Growth factor receptors signaling in glioblastoma cells: therapeutic implications. J Neurooncol. Vol. 92, No. 2, pp. 13747. PMID - 19043776

Chu SH, Zhu ZA, Yuan XH, Li ZQ, Jiang PC (2006). In vitro and in vivo potentiating the cytotoxic effect of radiation on human U251 gliomas by the c-Met antisense oligodeoxynucleotides. J Neurooncol. Vol. 80, No. 2, pp. 143-9. PMID - 16648987 
Dreux AC, Lamb DJ, Modjtahedi H, Ferns GA (2006). The epidermal growth factor receptors and their family of ligands: their putative role in atherogenesis. Atherosclerosis. Vol. 186, No. 1, pp. 38-53. PMID - 15072443

Fallon JH, Seroogy KB, Loughlin SE, Morrison RS, Bradshaw RA, Knaver DJ, Cunningham DD (1984). Epidermal growth factor immunoreactive material in the central nervous system: location and development. Science. Vol. 224, No. 4653, pp. 1107-9. PMID - 6144184

Grierson I, Heathcote L, Hiscott P, Hogg P, Briggs M, Hagan S. (2000). Hepatocyte growth factor/scatter factor in the eye. Prog Retin Eye Res. Vol. 19, No. 6, pp. 779-802. PMID $-11029554$

Guessous F, Zhang Y, diPierro C, Marcinkiewicz L, Sarkaria J, Schiff D, Buchanan S, Abounader R. (2010). An orally bioavailable c-Met kinase inhibitor potently inhibits brain tumor malignancy and growth. Anticancer Agents Med Chem. Vol. 10, No. 1, pp. 28-35. PMID - 20015006

Guiu S, Taillibert S, Chinot O, Taillandier L, Honnorat J, Dietrich PY, Maire JP, Guillamo JS, Guiu B, Catry-Thomas I, Capelle F, Thiebaut A, Cartalat-Carel S, Deville C, Fumoleau P, Desjardins A, Xuan KH, Chauffert B. (2008). Bevacizumab/irinotecan. An active treatment for recurrent high-grade gliomas: preliminary results of an ANOCEF multi-center study. Rev Neurol (Paris). Vol. 164, No. 7, pp. 588-94. PMID 1856535

Hadjipanayis CG, Van Meir EG. (2009a). Brain cancer propagating cells: biology, genetics and targeted therapies. Trends Mol Med. Vol. 14, No. 11, pp. 519-30. PMID 19889578

Hadjipanayis CG, Van Meir EG. (2009b). Tumor initiating cells in malignant gliomas: biology and implications for therapy. J Mol Med. Vol. 87, No. 4, pp. 363-74. PMID 19189072

Hirose Y, Kojima M, Sagoh M, Murakami H, Yoshida K, Shimazaki K, Kawase T. (1998). Immunohistochemical examination of c-Met protein expression in astrocytic tumors. Acta Neuropathol (Berl). Vol. 95, No. 4, pp. 345-51. PMID - 9560011

Hormigo A, Gu B, Karimi S, Riedel E, Panageas KS, Edgar MA, Tanwar MK, Rao JS, Fleisher M, DeAngelis LM, Holland EC (2006). YKL-40 and matrix metalloproteinase-9 as potential serum biomarkers for patients with high-grade gliomas. Clin Cancer Res Vol. 12, No. 19, pp 5698-5704. PMID - 17020973

Ji H, Wang J, Fang B, Fang X, Lu Z. (2010). a-Catenin inhibits glioma cell migration, invasion, and proliferation by suppression of b-catenin transactivation. $J$ Neurooncol. (Epub ahead of print). PMID - 20872274

Kim KJ, Wang L, Su YC, Gillespie GY, Salhotra A, Lal B, Laterra J (2006). Systemic antihepatocyte growth factor monoclonal antibody therapy induces the regression of intracraneal glioma xenografts. Clin Cancer Res. Vol. 12, No. 4, pp. 1292-98. PMID 16489086

Kimura F, Miyazaki M, Suwa T, Kakizaki S, Itoh H, Kaiho T, Ambiru S, Shimizu H, Togawa A. (1996). Increased levels of human hepatocyte growth factor in serum and peritoneal fluid after partial hepatectomy. Am J Gastroenterol. Vol. 91, No. 1, pp. 116-21. PMID - 8561110 
Koochekpour S, Jeffers M, Rulong S, Taylor G, Klineberg E, Hudson EA, Resau JH, Vande Woude GF. (1997). Met and hepatocyte growth factor/scatter factor expression in human gliomas. Cancer Res. Vol. 57, No. 23, pp. 5391-98. PMID - 9393765

Lal B, Xia S, Abounader R, Laterra J (2005). Targeting the c-Met pathway potentiates glioblastoma responses to gamma-radiation. Clin Cancer Res. Vol. 11, No. 12, pp. 4479-86. PMID - 15958633

Lamszus K, Jin L, Fuchs A, Shi E, Chowdhury S, Yao Y, Polverini PJ, Laterra J, Goldberg ID, Rosen EM. (1997). Scatter factor stimulates tumor growth and tumor angiogenesis in human breast cancers in the mammary fat pads of nude mice. Lab Invest. Vol. 76, No. 3, pp. 339-53. PMID - 9121117

Lamszus K, Laterra J, Westphal M, Rosen E. (1999). Scatter factor/ hepatocyte growth factor (SF/HGF) content and function in human gliomas. Int J Dev Neurosci. Vol. 17, No. 5-6, pp. 517-30. PMID - 10571413

Lantos PL, Louis DN, Rosenblum MK, Kleihues P (2002). Tumours of the Nervous System. Oxford University Press: London.

Laterra J, Rosen E, Nam M, Ranganathan S, Fielding K, Johnston P. (1997). Scatter factor/hepatocyte growth factor expression enhances human glioma tumorigenicity and growth. Biochem Biophys Res Commun. Vol. 235, No. 3, pp. 743-7. PMID - 9207232

Louis D.N., Ohgaki H., Wiestler O.D., Cavenee W.K. (2007) WHO Classification of Tumours of the Central Nervous System. IARC: Lyon 2007.

Mentlein R, Forstreuter F, Mehdorn HM, Held-Feindt J. (2004). Functional significance of vascular endothelial growth factor receptor expression on human glioma cells. $J$ Neurooncol. Vol. 67, No. 1-2, pp. 9-18. PMID - 15072443

Miwa Y, Harrison PM, Farzaneh F, Langley PG, Williams R, Hudges RD. Plasma levels and hepatic mRNA expression of transforming factor-beta 1 in patients with hepatic fulminant failure. J Hepatol. Vol. 27, No. 5, pp. 780-88. PMID - 9382963

Moriyama T, Kataoka H, Koono M, Wakaisaka S. (1999). Expression of hepatocyte growth factor/scatter factor and its receptor c-Met in brain tumors: evidence for a role in progression of astrocytic tumors. Int J Mol Med. Vol. 3, No. 5, pp. 531-36. PMID 10202187

Nabeshima K, Shimao Y, Sato S, Kataoka H, Moriyama T, Kawano H, Wakisaka S, Koono M. (1997). Expression of c-Met correlates with grade of malignancy in human astrocytic tumours: an immunohistochemical study. Histopathology. Vol. 31, No. 5, pp. 436-43. PMID - 9416484

Narayana A, Kelly P, Golfinos J, Parker E, Johnson G, Knopp E, Zagzag D, Fischer I, Raza S, Medabalmi P, Eagan P, Gruber ML. (2009). Antiangiogenic therapy using bevacizumab in recurrent high-grade glioma: impact on local control and patient survival. J Neurosurg. Vol. 110, No. 1, pp. 173-180. PMID - 18834263

Neaud V, Faouzi S, Guirouilh J, Le Bail B, Balabaud C, Bioulac-Sage P, Rosenbaum J. (1997). Human hepatic myofibroblast increase invasiveness of hepatocellular carcinoma cells: evidence for a role of hepatocyte growth factor. Hepatology. Vol. 26, No. 6, pp. 1458-66. PMID - 9397985

Nghiemphu PL, Liu W, Lee Y, Than T, Graham C, Lai A, Green RM, Pope WB, Liau LM, Mischel PS, Nelson SF, Elashoff R, Cloughesy TF. (2009). Bevacizumab and 
chemotherapy for recurrent glioblastoma: a single-institution experience. Neurology. Vol. 72, No. 14, pp. 1217-22. PMID - 19349600

Oblinger JL, Pearl DK, Boardman CL, Saqr H, Prior TW, Scheithauer BW, Jenkins RB, Burger PC, Yates AJ (2006). Diagnostic and prognostic value of glycosyltransferase mRNA in glioblastoma multiforme patients. Neuropathol Appl Neurobiol. Vol. 32, No. 4, pp. 410-18. PMID - 16866986

Ohgaki H, Dessen P, Jourde B, Horstmann S, Nishikawa T, Di Patre PL, Burkhard C, Schuler D, Probst-Hensch NM, Maiorka PC, Baeza N, Pisani P, Yonekawa Y, Yasargil MG, Lutolf UM, Kleihues P (2004). Genetic pathways to glioblastoma: a populationbased study. Cancer Res, Vol. 64, No. 19, pp. 6892-99. PMID - 15466178

Ohgaki H, Kleihues P (2007). Genetic pathways to primary and secondary glioblastoma. Am J Pathol, Vol. 170, No. 5, pp 1445-53. PMID - 17456751

Pelloski CE, Mahajan A, Maor M, Chang EL, Woo S, Gilbert M, Colman h, Yang H, Ledoux A, Blair H, Passe S, Jenkins RB, Aldape KD (2005). YKL-40 expression is associated with poorer response to radiation and shorter overall survival in glioblastoma. Clin Cancer Res. Vol. 11, No. 9, pp. 3326-34. PMID - 15867231

Peruzzi, B. and Bottaro, D.P. (2006). Targeting the c-Met signaling pathway in cancer. Clin. Cancer Res. Vol. 12, No. 12, pp. 3657-60. PMID - 16778093

Pope WB, Lai A, Nghiemphu P, Mischel P, Cloughesy TF. (2006). MRI in patients with highgrade gliomas treated with bevacizumab and chemotherapy. Neurology. Vol. 66, No. 8, pp. 1258-60. PMID - 16636248

Poulsen HS, Grunnet K, Sorensen M, Olsen P, Hasselbalch B, Nelausen K, Kosteljanetz M, Lassen U. (2009). Bevacizumab plus irinotecan in the treatment patients with progressive recurrent malignant brain tumours. Acta Oncol. Vol. 48, No. 1, pp. 5258. PMID - 19031176

Schmidt NO, Westphal M, Hagel C, Ergün S, Stavrou D, Rosen EM, Lamszus K. (1999). Levels of vascular endothelial growth factor, hepatocyte growth factor/scatter factor and basic fibroblast growth factor in human gliomas and their relation to angiogenesis. Int J Cancer. Vol. 84, No. 1, pp. 10-18. PMID - 9988225

Stella MC, Comoglio PM. (1999). HGF: a multifunctional growth factor controlling cell scattering. Int J Biochem Cell Biol. Vol. 31, No. 12, pp. 1357-62. PMID - 10641789

Takeuchi E, Nimura Y, Nagino M, Kurumiya Y, Maeda A, Kamiya J, Kondo S, Kanai M, Miyachi M, Uesaka K, Yoshida S. (1997). Human hepatocyte growth factor in bile: an indicator of posthepatectomy liver function in patients with biliary tract carcinoma. Hepatology. Vol. 26, No. 5, pp. 1092-99. PMID - 9362347

Tan D, Xu J, Li Y, Lai R. (2010). Association between +61G polymorphism of the EGF gene and glioma risk in different ethnicities: a meta-analysis. Tohoku J Exp Med. Vol. 222, No. 4, pp. 229-35. PMID - 21123997

Trusolino L, Cavassa S, Angelini P, Andó M, Bertotti A, Comoglio PM, Boccaccio C. (2000). HGF/scatter factor selectively promotes cell invasion by increasing integrin avidity. FASEB J. Vol. 14, No. 11, pp. 1629-40. PMID - 10928998

Van Meir EG, Hadjipanayis CG, Norden AD, Shu HK, Wen PY, Olson JJ.. (2010). Exciting New Advances in Neuro-Oncology: The Avenue to a Cure for Malignant Glioma. CA Cancer J Clin. Vol. 60, No. 3, pp 166-193. PMID - 20445000

Wen PY, Schiff D, Cloughesy TF, Raizer JJ, Laterra J, Smitt M, Wolf M, Oliner KS, Anderson A, Zhu M, Loh E, Reardon DA. (2011). A phase II study evaluating the efficacy and 
safety of AMG 102 (rilotumumab) in patients with recurrent glioblastoma. Neuro Oncol. Vol. 13, No. 4, pp. 437-46. PMID - 21297127

Wood GW, Morantz RA. (1983). Depressed T lymphocyte function in brain tumor patients: monocytes as suppressor cells. J Neurooncol. Vol. 1, No. 2, pp. 87-94. PMID 6236289

Xian CJ, Li L, Deng YS, Zhao SP, Zhou XF. (2001). Lack of effects of transforming growth factor-alpha gene knockout on peripheral nerve regeneration may result from compensatory mechanisms. Exp Neurol. Vol. 172, No. 1, pp. 182-8. PMID - 11681850

Xiao G, Jeffers M, Bellacosa A, Mitsuuchi Y, Vande Woude G, Testa J. (2001). Anti-apoptotic signaling by hepatocyte growth factor/Met via the phosphatidylinositol 3kinase/Akt and mitogen activated protein kinase pathways. Proc Natl Acad Sci. Vol.98, No. 1, pp. 247-52. PMID - 11134526

Yamada T, Tsubouchi H, Daikuhara Y, Prat M, Comoglio PM, McGeer PL, McGeer (1994). Immunohistochemistry with antibodies to hepatocyte growth factor and its receptor protein (c-Met) in human brain tissues. Brain Res. Vol. 637, No. 1-2, pp. 308-12. PMID - 8180811

Zuniga RM, Torcuator R, Jain R, Anderson J, Doyle T, Ellika S, Schultz L, Mikkelsen T.. (2009). Efficacy, safety and patterns of response and recurrence in patients with recurrent high-grade gliomas treated with bevacizumab plus irinotecan.J Neurooncol. Vol. 91, No. 3, pp. 329-36. PMID - 18953493 


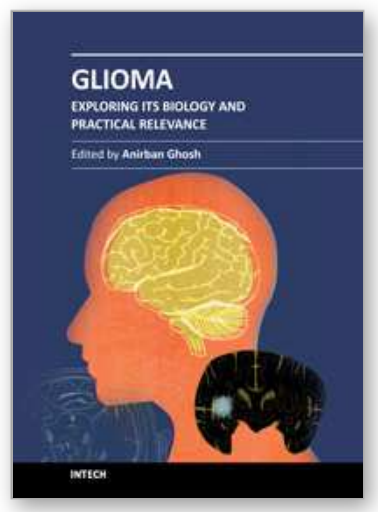

\author{
Glioma - Exploring Its Biology and Practical Relevance \\ Edited by Dr. Anirban Ghosh
}

ISBN 978-953-307-379-8

Hard cover, 486 pages

Publisher InTech

Published online 02, November, 2011

Published in print edition November, 2011

The tittle 'Glioma - Exploring Its Biology and Practical Relevance' is indicative of its content. This volume contains 21 chapters basically intended to explore glioma biology and discussing the experimental model systems for the purpose. It is hoped that the present volume will provide supportive and relevant awareness and understanding on the fundamental advances of the subject to the professionals from any sphere interested about glioma.

\title{
How to reference
}

In order to correctly reference this scholarly work, feel free to copy and paste the following:

Roberto Garcia-Navarrete, Esperanza Garcia Mendoza, Alfonso Marhx-Bracho and Julio Sotelo (2011). Biological Markers of Recurrence and Survival of High-Grade Gliomas: The Role of Hepatocyte Growth Factor, Glioma - Exploring Its Biology and Practical Relevance, Dr. Anirban Ghosh (Ed.), ISBN: 978-953-307-379-8, InTech, Available from: http://www.intechopen.com/books/glioma-exploring-its-biology-and-practicalrelevance/biological-markers-of-recurrence-and-survival-of-high-grade-gliomas-the-role-of-hepatocyte-growthfa

\section{INTECH}

open science | open minds

\section{InTech Europe}

University Campus STeP Ri Slavka Krautzeka 83/A 51000 Rijeka, Croatia Phone: +385 (51) 770447

Fax: +385 (51) 686166 www.intechopen.com

\section{InTech China}

Unit 405, Office Block, Hotel Equatorial Shanghai No.65, Yan An Road (West), Shanghai, 200040, China 中国上海市延安西路65号上海国际贵都大饭店办公楼 405 单元 Phone: +86-21-62489820

Fax: $+86-21-62489821$ 
(C) 2011 The Author(s). Licensee IntechOpen. This is an open access article distributed under the terms of the Creative Commons Attribution 3.0 License, which permits unrestricted use, distribution, and reproduction in any medium, provided the original work is properly cited. 